\title{
Experimental evaluation of anaerobic digestion for coffee wastewater treatment and its biomethane recovery potential
}

\author{
A. Beyene - D. Yemane - T. Addis • \\ A. A. Assayie $\cdot$ L. Triest
}

Received: 16 December 2012/Revised: 23 March 2013/Accepted: 6 May 2013/Published online: 29 May 2013

(C) Islamic Azad University (IAU) 2013

\begin{abstract}
The objective of this study was to evaluate the performance of anaerobic digestion (AD) as an ecofriendly technology for coffee wastewater (CWW) management. First, we have characterized the CWW and found that it is suitable for microbial degradation with $\mathrm{pH}$ adjustment. Then, we designed a simple anaerobic batch reactor $(\mathrm{ABR})$ and evaluated its potential for energy yield and efficiency to remove pollutants. The experiment was carried out by operating the anaerobic digestion (AD) for 70 days. The ABR was found to be efficient for the removal of organic load $(90 \%)$, nutrients $(82 \%)$ and suspended solids $(95 \%)$ from coffee processing waste. The increased removal efficiency of pollutants was dependent on the hydraulic retention time of the system. We also estimated that the coffee waste has a potential to produce a theoretical energy yield of 4-10 million $\mathrm{KJ} /$ day and an organic fertilizer (digestate) of $18.8-25.2 \mathrm{~kg} \mathrm{VSS} /$ day. As a result, the $\mathrm{AD}$ would be a more sensible consideration as an eco-friendly treatment option for the coffee waste. The use of $\mathrm{AD}$ for $\mathrm{CWW}$ treatment not only reduces emission of greenhouse gases to the environment but also circumvents the rising demand for fuel wood and charcoal that causes a severe deforestation in the coffee growing regions of the world.
\end{abstract}

A. Beyene and D. Yemane have contributed to this work equally.

A. Beyene $(\bowtie) \cdot$ D. Yemane $\cdot$ T. Addis · A. A. Assayie Department of Environmental Health Science and Technology, Jimma University, Po.Box: 378, Jimma, Ethiopia

e-mail: abebe.beyene@ju.edu.et

A. A. Assayie - L. Triest

Biology Department, Vrije Universiteit Brussel,

Pleinlaan 2, 1050 Brussels, Belgium
Keywords Anaerobic digestion - Biogas potential . Coffee wastewater - Organic fertilizer

\section{Introduction}

Environmental pollution because of improper waste management is an alarming challenge for developing countries to meet the millennium development goals. Several studies reported that untreated waste from traditional and modern industries is threatening surface waters worldwide, and it is severe in developing countries (Beyene et al. 2011). Water pollution is the gloomy setback for the development in coffee producing countries (Mwaura and Mburu 1998; Varunprasath and Daniel 2010), and this also appears to be the case in Ethiopia (Haddis and Devi 2008; Beyene 2010). Traditional shedding coffee plantation system, which has social and economic value (Vergara and Badano 2009) with minimal impact on biodiversity and environment (Perfecto et al. 1996; Gordon et al. 2007; López-Gómez et al. 2008), prevails in Jimma Zone. Nevertheless, untreated waste materials from coffee processing are routinely discharged into local streams without treatment and caused a severe ecological disruption (Beyene et al. 2011). Coffee processing is vilified for the production of byproducts such as parchment husks, coffee pulp and coffee husks all of which contribute to environmental pollution unless treated or recycled (Mburu and Mwaura 1996).

The wet coffee processing method, commonly used in Ethiopia and other coffee growing countries, requires huge amount of water to remove the coffee pulp mechanically resulting in the production of considerable quantity of wastewater with high levels of organic matter. For instance, Ethiopia produced about 207, 000 tons of washed coffee beans by the year 2010 (Ethiopian-CSA 2011). It is 
known that $100 \mathrm{~g}$ of coffee cherry yields $39.45 \mathrm{~g}$ of coffee beans (CBCP 2006). A typical traditional coffee processing industry uses $5-15 \mathrm{~L}$ of water to produce $1 \mathrm{~kg}$ of clean coffee beans (Hue et al. 2004). Thus, to produce 207,000 tons washed coffee beans, 317,314 tons of untreated solid waste (mucilage plus pulp) and $10.35 \times 10^{5}-31.05 \times 10^{5}$ cubic meters of untreated wastewater were released to the nearby water sources. Although this huge amount of coffee waste emanating from the traditional coffee processing industries in Ethiopia is a valuable resource for biogas, compost and animal feed, it is disposed to the nearby surface water without treatment (Beyene et al. 2011). As a result, it becomes a severe threat to the aquatic ecosystem and downstream users. Hence, the focus of this research was to characterize the coffee wastewater $(\mathrm{CWW})$ and verify the performance of anaerobic digestion as an eco-friendly management technology in terms of producing clean energy and natural fertilizers from the enormous amount of organic waste.

The disposal of wastewater on land is probably the cheapest and easiest method for treating seasonal wastes. For instance, waste stabilization pond technology is a flexible treatment process, which is usually simple in design and offers low-cost construction, operation and maintenance options (Dalu and Ndamba 2003). Ponds can be used to combine both wastewater storage and treatment for subsequent reuse in aquaculture and agriculture (Racault et al. 1995). However, in these wastewater treatment options, there is no economic value that can be accrued from the waste and contaminants can seep and reach to the ground water or surface water by percolation and runoff. Moreover, these waste treatment options emit greenhouse gases (e.g., methane and carbon dioxide) to the atmosphere that can aggravate the alarming global warming and climate change. As a result, an eco-friendly waste treatment technology is required to avert the environmental damage related to coffee wastewater.

Recently, anaerobic digestion (AD) is considered as an environmentally sound biological treatment process (Neves et al. 2006). The AD process has several advantages over other wastewater treatment methods. For example, it minimizes the use of large areas of land, avoids nuisance and bad odor, and reduces organic load and pathogens while methane and organic fertilizer are obtained as final metabolic end products (Holm-Nielsen et al. 2009).

Understanding the nature of wastewater is essential in the design and operation of collection, treatment and reuse facilities. It also helps in the choice of treatment methods, in deciding the extent of treatment and in assessing the beneficial uses of wastes (Tchobanoglous et al. 2003). Therefore, the first objective of this research is to characterize the physicochemical constituents of the CWW.
The AD has potential economic benefits because of the end products of methane as an energy and slurry as an organic fertilizer that makes it one of the best possible options for CWW management. Consequently, the second objective of this research is to design and demonstrate a laboratory-scale $\mathrm{AD}$ for the $\mathrm{CWW}$ and to evaluate its removal efficiencies of organic load, suspended solids and nutrients as well as its potential for resources recovery (biogas and organic fertilizer). The experiments were conducted from November 1, 2010, to April 30, 2011, at the laboratory of Environmental Health Science and Technology Department, Jimma University, Ethiopia.

\section{Materials and methods}

\section{Study area}

The study area is located in Jimma Zone, the former capital of Kaffa province, in Ethiopia. This area is known for growing coffee. It is located $390 \mathrm{~km}$ southwest of Addis Ababa. Kaffa province is the origin of highland coffee (Coffea arabica Linnaeus) plant. This coffee tree species, the only native coffee in the world, has traditionally been tended and harvested as a wild tree in the highland forests of southwestern Ethiopia (Schmitt 2006), mostly in the former Kaffa province. There are more than 53 traditional coffee processing industries located in Jimma Zone, and none of them were using an eco-friendly technology to treat their waste.

\section{Wastewater sampling and sample analysis}

Wet coffee processing in Jimma Zone usually begins at the end of August and proceeds until mid-December. Consequently, we collected samples in November 2010 (the month of the year for peak wet coffee processing). Although all the coffee processing plants are following the same wet coffee processing method and expected to produce wastewater of similar composition, we randomly selected six coffee processing plants to make the samples more representative for wastewater characterization and laboratory-scale $\mathrm{AD}$ evaluation.

We collected $130 \mathrm{~L}$ of composite CWW samples from the effluents of the selected coffee processing plants using large size polyethylene jerrican for characterization and $\mathrm{AD}$ input. In order to have representative composite samples, the wastewater was collected at the peak hours of coffee processing. The samples were properly and carefully sealed and transported to the laboratory of the Department of Environmental Health Science and Technology, Jimma University, Ethiopia. We maintained cold storage (below $4{ }^{\circ} \mathrm{C}$ ) throughout the process till analysis. 
The analysis of wastewater samples was performed strictly following the standard methods for the examination of water and wastewater (APHA 2005). Samples from the influent and supernatant at the end of anoxic phase (effluent) were analyzed for nutrients (total nitrogen (TN) and total phosphorus (TP)), and chemical oxygen demand (COD) colorimetrically using DR $5000^{\mathrm{TM}} \mathrm{UV}-\mathrm{V}$ is laboratory spectrophotometer (HACH Company, Loveland, USA) following the HACH instructions. Five-day biological oxygen demand $\left(\mathrm{BOD}_{5}\right)$ was measured based on the azide modification of the Winkler method, whereas total dissolved solids (TDS), total suspended solids (TSS) and volatile suspended solids (VSS) were measured using the gravimetric method. The analysis was made in triplicate for each parameter.

Experimental set-up and operation of ABR system

Three laboratory-scale anaerobic batch reactors (ABR1, ABR2 and ABR3) were designed and tested for CWW treatment at the laboratory. The reactors were placed within room temperature range $\left(20-23{ }^{\circ} \mathrm{C}\right)$. The three reactors have equal working volumes of $40 \mathrm{~L}$. They were complemented by one air tight faucet to take effluent sample and a manual stirrer for mixing. The collected CWW effluent was mixed, and the $\mathrm{pH}$ was adjusted to about 7.0 using sodium bicarbonate. Since the raw CWW lacks the necessary microbial population for efficient biodegradation, we added very little sludge from septic tank as seeding. It was loaded into the batch reactors and kept for 70 days to achieve a steady-state condition for efficient digestion as suggested by Gerardi (2003) and de la Rubia et al. (2006). The content of the ABRs was stirred manually for about 5-10 min during early morning and evening of each day to enhance the digestion process by distributing microbes, substrate and nutrients, and to equalize temperature throughout the digester. The $\mathrm{pH}$ was also maintained approximately neutral. Samples were taken from the anaerobic digesters every 10 days to evaluate the reactor performance for the removal of nutrients (TN and $\mathrm{TP})$, organic load $\left(\mathrm{BOD}_{5}\right.$ and COD) and solids (VSS, TDS and TSS). Using these measurements, we estimated biomethane and fertilizer potential of the CWW.

Data analysis

\section{Pollutant removal efficiency estimation}

Nutrient, organic load and suspended solid removal efficiency of the ABR were calculated using Eq. 1 (Clara et al. 2005).

Removal efficiency $(\%)=\frac{C_{\text {inf }}-C_{\text {eff }}}{C_{\text {inf }}} \times 100$ where $C_{\text {inf }}=$ initial parameter concentration and $C_{\text {eff }}=$ final parameter concentration.

\section{Biochemical methane potential (BMP) estimation}

The biogas potential was predicted based on the relationship between COD removed and amount of discharge (Droste 1997; Tchobanoglous et al. 2003). The BMP for the $\mathrm{AD}$ was determined using the quantity of methane per unit time (Qm) as presented in Eq. 2. (Droste 1997).

$Q \mathrm{~m}=Q *\left(\mathrm{ST}_{\mathrm{O}}-\mathrm{ST}_{\mathrm{e}}\right) * M=Q * E * M * \mathrm{ST}_{\mathrm{O}}$

where $\mathrm{Qm}$ is the quantity of methane per unit time; $Q$ is the influent flow rate; $\mathrm{ST}_{\mathrm{O}}$ is the total influent $\mathrm{COD} ; \mathrm{ST}_{\mathrm{e}}$ is the total effluent COD; $E$ is an efficiency factor (dimensionless, ranging from 0 to 1 ) and $M$ is the volume of methane $\left(\mathrm{CH}_{4}\right)$ produced per unit of COD.

\section{Sludge or organic fertilizer production estimation}

To estimate the sludge/digestate production rate, we used the measured experimental results and typical values for anaerobic reaction from Tchobanoglous et al. (2003). The quantity of sludge produced daily was estimated using Eq. 3.

$P_{\mathrm{x}}$, vss $=Y Q\left(S_{\mathrm{o}}-S\right) /[1+(\mathrm{kd}) \mathrm{HRT}] 0.85$

where $P_{\mathrm{x}}$,vss is the net organic fertilizer or sludge produced each day, and it is expressed as $\mathrm{kg} \mathrm{VSS/day;} Y$ is yield coefficient and calculated as gm of VSS/gm of COD; kd is the decay coefficient; HRT is the hydraulic retention time; $S_{\mathrm{o}}$ and $S$ are the influent and effluent substrate concentration in $\mathrm{mg} / \mathrm{l}$, respectively, and $Q$ is the influent flow rate in $\mathrm{m}^{3} /$ day.

\section{Results and discussion}

\section{Characterization of coffee wastewater}

The average influent and effluent characteristics of the composite raw CWW samples and the ABR treatment percent removal efficiencies for the parameters at different hydraulic retention time are presented in Table 1 and Fig. 1a-c, respectively. On average, the raw or influent CWW concentrations of $\mathrm{BOD}_{5}, \mathrm{COD}, \mathrm{TN}, \mathrm{TP}, \mathrm{TDS}, \mathrm{TSS}$ and VSS were $5,861,8,079,350,14.7,3,933,2,019$ and $1,089 \mathrm{mg} / \mathrm{l}$, respectively (Table 1 ). The raw CWW samples were characterized by high acidity with an average $\mathrm{pH}$ value of 3.57, high content of biodegradable organic matter $\left(\mathrm{BOD}_{5}=5,861 \mathrm{mg} / \mathrm{l}\right)$ and high nutrient content $(\mathrm{TN}=$ $350 \mathrm{mg} / \mathrm{l}$ and $\mathrm{TP}=14.7 \mathrm{mg} / \mathrm{l})$. The CWW was also characterized by high suspended solids (TSS $=2,019 \mathrm{mg} / \mathrm{l}$ and VSS $=1,089 \mathrm{mg} / \mathrm{l}$ ) and dissolved solids (TDS $=3,933 \mathrm{gm} / \mathrm{l}$ ). 
Table 1 Average concentration of physicochemical parameters in $\mathrm{mg} / \mathrm{l}$ starting from day zero (i.e., influent or raw wastewater) to the final 70 days of anaerobic digestion experiment

\begin{tabular}{|c|c|c|c|c|c|c|c|c|}
\hline Parameter & 0 (influent) & 10 & 20 & 30 & 40 & 50 & 60 & 70 \\
\hline \multicolumn{9}{|c|}{ Number of days } \\
\hline $\mathrm{BOD}_{5}$ & $5,861.0$ & $4,865.0$ & $4,454.0$ & $4,044.0$ & $2,198.0$ & $1,231.0$ & 820.0 & 410.3 \\
\hline COD & $8,079.0$ & $5,574.0$ & $4,605.0$ & $4,282.0$ & $3,877.0$ & $2,019.0$ & $1,293.0$ & 889.0 \\
\hline TDS & $3,933.0$ & $3,185.0$ & $2,556.0$ & $2,124.0$ & $1,258.0$ & $1,022.0$ & 747.0 & 438.9 \\
\hline TSS & $2,019.0$ & $1,352.0$ & $1,131.0$ & 989.0 & 908.6 & 787.4 & 424.0 & 195.0 \\
\hline VSS & $1,089.0$ & 860.3 & 664.0 & 653.0 & 577.2 & 261.0 & 119.8 & 74.0 \\
\hline $\mathrm{TN}$ & 350.0 & 304.0 & 269.6 & 262.0 & 178.5 & 143.5 & 101.5 & 63.0 \\
\hline $\mathrm{TP}$ & 14.7 & 10.7 & 9.8 & 7.2 & 4.5 & 4.3 & 2.2 & 0.4 \\
\hline
\end{tabular}

Fig. 1 The average pollutants (a organic load, b dissolved and suspended solids and c nutrients) removal efficiency of the three ABR experiments conducted for a maximum of 70 days
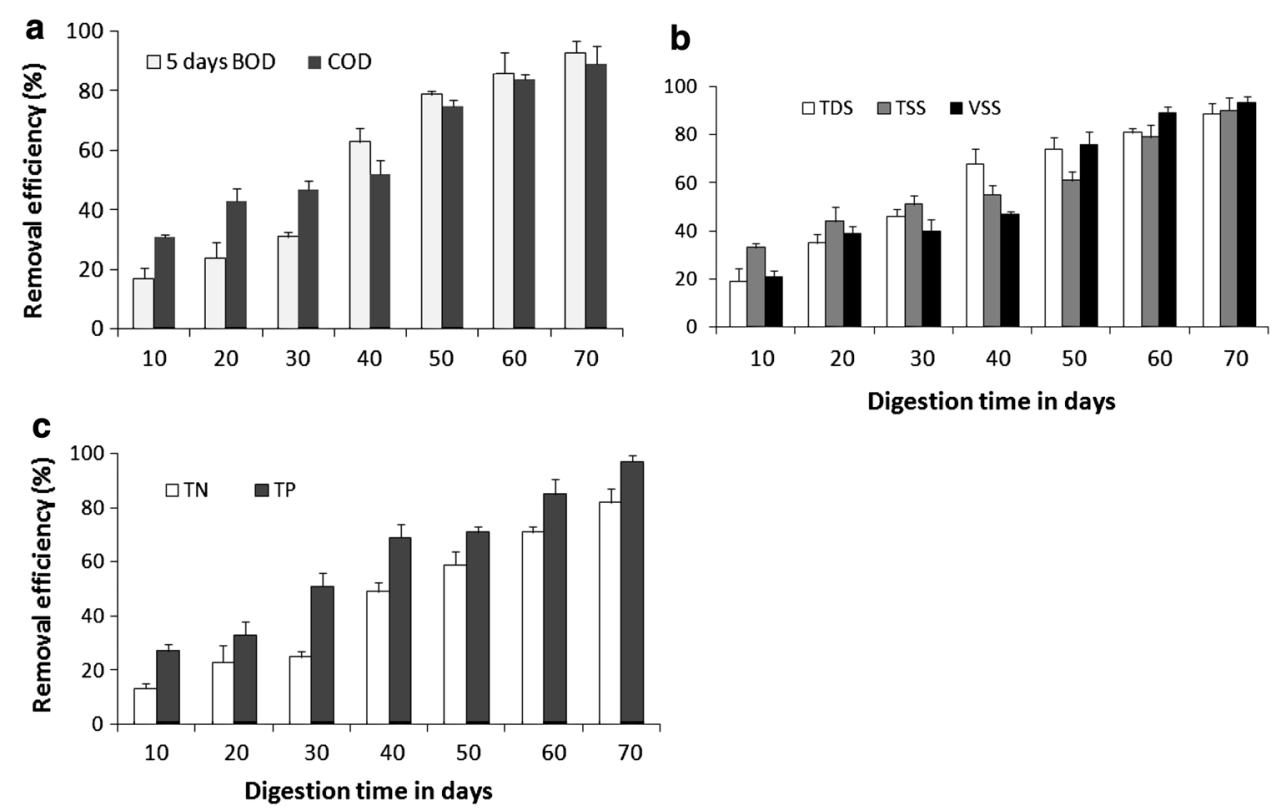

The finding of this study is in agreement with other similar studies conducted in Ethiopia (e.g., Haddis and Devi 2008) and Kenya (e.g., Mburu et al. 1994), indicating that CWW is rich in organic matter and nutrients. The acidic characteristic of the CWW is due to the fact that pectin and sugar are fermenting to alcohol and vinegar or acetic acid. This result indicated that the $\mathrm{pH}$ needs to be neutralized to a level between 6.5 and 7.5 in order to initiate and optimize the anaerobic digestion process of the CWW.

Evaluation of coffee wastewater treatment performance of the ABR

The removal percent efficiencies of organic load $\left(\mathrm{BOD}_{5}\right.$ and COD) in Fig. 1a, suspended solids (TSS and VSS) in Fig. 1b and nutrients (TN and TP) in Fig. 1c showed that a decrease at a subtle rate until the 30th day in all parameters. A drastic reduction in all parameters was observed after 40 days of acclimatization. However, this high rate of reduction gradually stabilized after 50 days. For a normal anaerobic digestion process, reduction in an organic waste starts after 10 days and might stabilize and acclimatize after 20 days (McCarty 1964). Although the finding of this research is in agreement with the time taken to start the digestion process, acclimatization and stabilization took a relatively longer time (50 days). This indicates that the coffee waste needs much more retention time to stabilize when compared to other organic wastes. Nevertheless, in this experiment, we used manual mixing at regular time intervals that might contribute for the longer stabilization time. Thus, the retention time might be reduced by applying continuous mixing. Moreover, application of effluent recycling (adapted microbes) and waste pre-treatment (Uan et al. 2013) can shorten further the stabilization time.

The ABR removal efficiency of organic load and total solids was above $90 \%$, and for nutrients, it was about $82 \%$ (Fig. 1a-c). The anaerobic waste treatment system has been widely used for municipal waste treatment (Racault et al. 1995; Mata-Alvarez 2003); however, it has not been used for the treatment of coffee waste. This result 


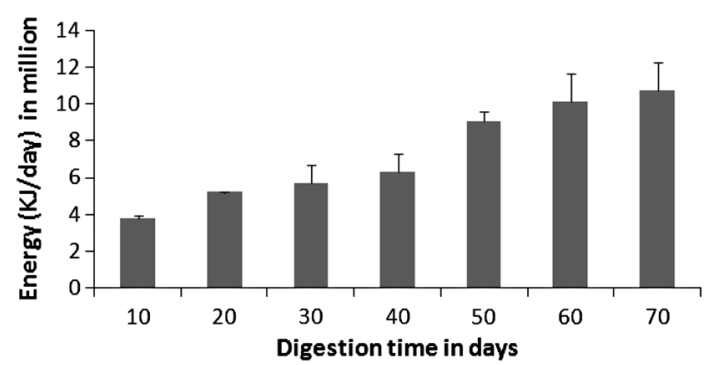

Fig. 2 The estimated average biochemical methane potential of the coffee wastewater of the three ABR experiments conducted for 70 days

revealed that $\mathrm{AD}$ is an eco-friendly waste management option to treat the coffee wastewater effectively.

Biochemical methane potential (BMP) of the coffee wastewater

The calculations for the BMP were based on the maximum theoretical methane yield of $0.4 \mathrm{~m}^{3} \mathrm{CH}_{4} / \mathrm{kg} \mathrm{COD}$ for temperature range of $30-40{ }^{\circ} \mathrm{C}$ as stipulated by Droste (1997). A flow rate of $147 \mathrm{~m}^{3} / \mathrm{d}$, average influent COD concentration of $8,079 \mathrm{mg} / \mathrm{l}$ and average effluent COD concentration of 2,019 $\mathrm{mg} / \mathrm{l}$ after 50-day retention time were also considered for the BMP estimation. The estimated BMP revealed that the maximum possible energy recovered after 50 days of digestion process is about 10 million $\mathrm{KJ}$ energy per day (Fig. 2). In a similar calculation for 10 days of digestion, it is also possible to get about 4 million KJ energy per day. BMP estimation suggests that the $\mathrm{CH}_{4}$ recovery from the anaerobic digestion system will be a worthwhile consideration during coffee processing seasons. The $\mathrm{CH}_{4}$ recovered from anaerobic digestion systems is normally of a good quality. $\mathrm{AD}$ is not only beneficial for energy recovery but also significantly reduces the emission of $\mathrm{CH}_{4}$ and $\mathrm{CO}_{2}$ into the atmosphere (Pearson 1996; Fruergaard et al. 2009). In terms of pollution control, carbon conversion efficiencies in anaerobic digestion systems have been reported to range from 75 to $85 \%$ when operating at optimal conditions (Racault et al. 1995; Pearson 1996). Hence, the use of controlled anaerobic digestion to treat $\mathrm{CWW}$ is relevant in reducing substantial amount of greenhouse gases and direct environmental pollution.

Organic fertilizer recovery from the anaerobic digestion of the coffee wastewater

For the estimation of sludge or organic fertilizer, a typical anaerobic reaction value of yield coefficient $(0.08 \mathrm{~g} \mathrm{VSS} / \mathrm{g}$ COD) and a decay coefficient of $0.03 \mathrm{~g} \mathrm{VSS} / \mathrm{g}$ VSS.d for a temperature range of $30-40{ }^{\circ} \mathrm{C}$ were used (Droste 1997). The COD value of influent concentration was $8,079 \mathrm{mg} / \mathrm{l}$ (measured) and effluent concentration was $889 \mathrm{mg} / \mathrm{l}$ (calculated), and the wastewater flow rate was $117.6 \mathrm{~m}^{3} / \mathrm{d}$ (calculated) at 70 days of retention time. Substituting these values in the Eq. 3 that was used for estimating digestate gives a VSS within the range of $18.78-25.23 \mathrm{~kg} \mathrm{VSS} / \mathrm{d}$. This huge amount of an organic fertilizer can be recovered on daily basis. However, this valuable resources are lost by discharging the CWW directly into the surrounding environment that caused a serious environmental pollution as reported by several studies (Haddis and Devi 2008; Beyene 2010; Beyene et al. 2011). Anaerobic digestion mineralized the nutrients into more soluble and biologically available forms, and hence, the digestate has higher bio-available nutrients than in untreated organic waste. For example, Monnet (2003) reported that digestate has $25 \%$ more accessible $\mathrm{NH}_{4}-\mathrm{N}$ (inorganic nitrogen) value than untreated liquid wastes. Therefore, the digestate can be used as fertilizer or soil amendment in agriculture. Such use permits the creation of a nutrient cycling and maintains or improves soil structure due to the application of organic matter. In addition, natural organic fertilizer contains relatively diversified nutrients and has slow and quick acting manurial effect. Concurrently, it is capable of promoting the growth of crops and the activity of soil microbes while preserving the fertility of soil (Mäder and Fliessbach 2002). This can reduce the consumption of chemical fertilizer which in turn minimizes the agricultural cost and protect the soil.

In general, the considerable large amount of energy and organic fertilizer that can be recovered from the AD and its high efficiency in removing pollutants makes it as one of the best technologies for coffee waste management. Huge amount of untreated coffee waste has been generated by traditional coffee processing industries and dumped to the nearby water courses. Such an alarming pollution in the region calls for an urgent action and seeks a sound waste management option in order to ensure sustainability of coffee production and to avoid irreversible environmental damage. If business as usual scenario is continued, the economic gains accrued as a result of coffee export will be worthless due to the alarming water quality degradation and aquatic ecosystem disturbance. Therefore, this clean technology needs to be advocated and implemented in the coffee growing countries in order to address the environmental pollution arising from discharging of untreated CWW.

\section{Conclusion}

We introduced and tested anaerobic digestion (AD) process as an eco-friendly alternative solution for waste treatment and management to implement in the coffee growing regions. Based on our experimental results, the laboratoryscale anaerobic treatment system was found to be efficient in removing pollutants. The removal efficiency of $\mathrm{AD}$ for 
organic load and total solids was above $90 \%$ and about $82 \%$ for nutrients. The estimated biochemical methane potential (BMP) revealed that the possible energy recovery ranges from 4 to 10 million KJ/day. Generally, the amount of energy that can be recovered on a daily basis was increased as a function of hydraulic retention time (HRT), and the optimum range of the energy recovery corresponds to 40-50 days of HRT. Biogas recovery from anaerobic digesters yields clean and green resources with significant financial and environmental value. Particularly, for developing countries like Ethiopia, this biogas recovery will circumvent the needless rising demand for fuel wood and charcoal, which causes a halo of deforestation. A considerable amount of organic fertilizer in the range of $18.78-25.23 \mathrm{~kg}$ VSS/d can also be recovered on daily basis. Therefore, as urgent intervention measure in the areas of traditional coffee processing industries, anaerobic digestion for waste treatment and management options should be dealt with top priority to avoid further damage to the environment.

Acknowledgments The authors would like to thank Jimma Zone traditional coffee processing cooperatives for their collaboration during coffee wastewater sampling. We are also grateful to Jimma University, Ethiopia, for financial and logistic support and VLIRUOS, Belgium, for sponsoring short-term $\mathrm{PhD}$ plus research stay of Beyene A.

\section{References}

APHA (2005) Standard methods for examination of water and wastewater, 21st edn. American Public Health Association, American Water Works Association and the Water and Environment Federation, Washington

Beyene A (2010) Development and validation of ecological water quality monitoring tools for river systems of Ethiopia. VUB Press, Brussels

Beyene A, Kassahun Y, Addis T, Assefa F, Amsalu A, Legesse W, Kloos H, Triest L (2011) The impacts of traditional coffee processing on river water quality in Ethiopia and the urgency of adopting sound environmental practices. J Environ Monit Assess 184:7053-7063

CBCP (2006) Comprehensive industry document on coffee processing industry. Series: COINDS/62/2006-07. Central Pollution Control Board (CPCB), Indian Ministry of Environment and Forests, New Delhi, India

Clara M, Kreuzinger N, Strenn B, Gans O, Kroiss H (2005) The solids retention time-a suitable design parameter to evaluate the capacity of wastewater treatment plants to remove micropollutants. Water Res 39:97-106

Dalu JM, Ndamba J (2003) Duckweed based wastewater stabilization ponds for wastewater treatment (a low cost technology for small urban areas in Zimbabwe). Phy Chem Earth 28:1147-1160

de la Rubia MA, Pérez M, Romero LI, Sales D (2006) Effects of solids retention time (SRT) on pilot scale anaerobic thermophilic sludge digestion. Proc Biochem 41:79-86

Droste RL (1997) Theory and practice of water and wastewater treatment. Wiley, New York

Ethiopian-CSA (2011) The 2010 national statically abstract report. Central Statistics Authority (CSA), Addis Ababa, Ethiopia
Fruergaard T, Ekvall T, Astrup T (2009) Energy use and recovery in waste management and implications for accounting of greenhouse gases and global warming contributions. Waste Manage Res 27:724-737

Gerardi MH (2003) The microbiology of anaerobic digesters (Wastewater Microbiology Series). Wiley, New York

Gordon C, Manson R, Sundberg J, Cruz-Angón A (2007) Biodiversity, profitability, and vegetation structure in a Mexican coffee agro ecosystem. Agri Ecosyst Environ 118:256-266

Haddis A, Devi R (2008) Effect of effluent generated from coffee processing plant on the water bodies and human health in its vicinity. J Hazard Mater 152:259-262

Holm-Nielsen JB, Al Seadi T, Oleskowicz-Popiel P (2009) The future of anaerobic digestion and biogas utilization. Bioresour Technol 100:5478-5484

Hue NV, Bittenbender HC, Ortiz-Escobar ME (2004) Managing coffee processing water in Hawaii, Department of Tropical Plant and Soil Sciences, College of Tropical Agriculture and Human Resources, University of Hawaii, Manoa, Honolulu, HI 96822, USA

López-Gómez AM, Williams-Linera G, Manson RH (2008) Tree species diversity and vegetation structure in shade coffee farms in Veracruz, Mexico. Agri Ecosyst Environ 124:160-172

Mäder P, Fliessbach A (2002) Soil fertility and biodiversity in organic farming. Science 296:1694-1697

Mata-Alvarez J (2003) Biomethanization of the organic fraction of municipal solid waste. IWA Publishing, London

Mburu JK, Mwaura PK (1996) Environmentally sound management of coffee processing by-products: a review. Kenya Coffee 61:2237-2244

Mburu JK, Thuo JT, Marder RC (1994) The characterization of coffee waste water from coffee processing factories in Kenya. Kenya Coffee 59:1756-1763

McCarty PL (1964) Anaerobic waste treatment fundamentals. Public Works 95(9-12):91-95

Monnet F (2003) An introduction to anaerobic digestion of organic wastes. Available at: http://www.biogasmax.co.uk/media/introan aerobicdigestion. Accessed on 13 August 2012

Mwaura PK, Mburu JK (1998) Effect of wet processing of coffee on river water quality. Kenya Coffee 63:2779-2787

Neves L, Oliveira R, Alves MM (2006) Anaerobic co-digestion of coffee waste and sewage sludge. Waste Manag 26:176-181

Pearson HW (1996) Expanding the horizons of pond technology and application in an environmentally conscious world. Water Sci Technol 33:1-9

Perfecto I, Rice RA, Greenberg R, Van der Voort E (1996) Shade coffee: a disappearing refuge for biodiversity. Bioscience 46:598-608

Racault Y, Boutin C, Seguin A (1995) Waste stabilization ponds in France: a report on fifteen years experience. Water Sci Technol 31:91-101

Schmitt CB (2006). Montane rainforest with wild Coffea arabica in the Bonga region (SW Ethiopia): plant diversity, wild coffee management and implication for conservation. Ecology \& Development Series, No. 47 (pp. 1-161)

Tchobanoglous G, Burton FL, Stensel HD (2003) Wastewater engineering: treatment and reuse, 4th edn. McGraw-Hill, New York

Uan DK, Yeom IT, Arulazhagan P, Banu JR (2013) Effects of sludge pretreatment on sludge reduction in a lab-scale anaerobic/anoxic/ oxic system treating domestic wastewater. Int $\mathrm{J}$ Environ Sci Technol 10:495-502

Varunprasath K, Daniel NA (2010) Physico-chemical parameters of river Bhavani in three stations, Tamilnadu, India. Iranica $\mathbf{J}$ Energy Environ 1:321-325

Vergara CH, Badano EI (2009) Pollinator diversity increases fruit production in Mexican coffee plantations: the importance of rustic management systems. Agri Ecosyst Environ 129:117-123 